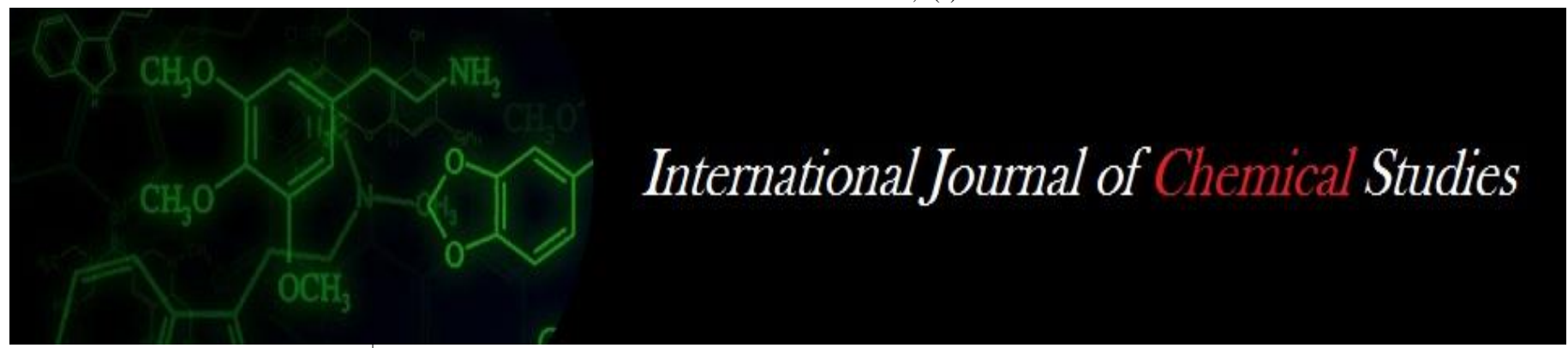

P-ISSN: 2349-8528

E-ISSN: 2321-4902

IJCS 2020; 8(1): 2556-2559

(C) 2020 IJCS

Received: 07-11-2019

Accepted: 09-12-2019

Mahendra Singh

Assistant Professor, College of

Agriculture Sciences,

Teerthanker Mahaveer

University, Moradabad,

Uttar Pradesh, India

Pramod Mall

Professor Department of

Entomology, Govind Ballabh

Pant University of Agriculture and Technology, Pantnagar,

Uttarakhand, India
Corresponding Author: Mahendra Singh Assistant Professor, College of Agriculture Sciences,

Teerthanker Mahaveer

University, Moradabad,

Uttar Pradesh, India

\section{Diversity and foraging behaviour of insects on mustard crop at Tarai region of Uttarakhand}

\author{
Mahendra Singh and Pramod Mall
}

DOI: https://doi.org/10.22271/chemi.2020.v8.i1am.8651

\begin{abstract}
The Tarai region of Uttarakhand area fall under Foothills of Himalayas and has a great diversity of flowering plants. This region was selected for maximum utilization of flora by beekeepers and recognizes the major pollen and nectar source to honeybees. The present study was conducted at Govind Ballabh Pant University of Agriculture and Technology, Pantnagar-263145, District Udham Singh Nagar (Uttarakhand) India, during the period 2011-2013. The Brassica campestris flowers visited by a number of pollinators. The hymenopterans were the major floral visitors of on Mustard crop. viz. Apidae (Apis dorsata, Apis mellifera, Apis cerana, Apis florae. In Apis dorsata mean foraging speed (time spent/ flower in seconds) 8.64 to 11.42 during different day hours of the day, while in case of Apis mellifera, Apis cerana, Apis florea it was 9.85 to $13.08,8.57$ to $9.42,11.42$ to 14.64 seconds. The maximum time (average 20.35 second) per flower was spent by Halictus ligatus.
\end{abstract}

Keywords: Pollen, bee-flora, foraging behaviour

\section{Introduction}

Agriculture is highly dependent on insect pollination, in particular by the honeybee. Pollination is the transfer of pollen from male to female reproductive structures of plants. In another words the process involving transfer of pollen from anthers to the stigma is called as pollination and the agent causing this transfer is called pollinator. Pollen is the fine powder like material consisting of pollen grains that is produced by the anthers of seed plants. When pollen from one flower is carried to the stigma of another, this is called cross-pollination. The economic value of insect pollination to agriculture can be estimated on the basis of the abundance and market value of insect pollinated crops. Pollination is thus one of the most important ecosystem services provided to agriculture. Pollination of crops by insects is an essential feature for the agriculture prosperity. There are many crops that do not set fruits or seeds without pollinators because these are self-incompatible and other compatible ones increase their production when pollinators are plentiful at a right moment the crop requires them. A pollinator is the biotic agent (vector) that moves pollen from the male anthers of a flower to the female stigma of a flower to accomplish fertilization or syngamy of the female gamete in the ovule of the flower by the male gamete from the pollen grain. A pollen grain is a marvelous product evolved by flowering plants to continue their generation. Pollination of flowers requires insect like syrphid flies, honey bees, ants and wasps (Das and Chodhury, 1968) ${ }^{[4]}$. The sustainable development of agriculture has necessitated the reorientation of the present crop production technologies (Free, 1993; Abrol, 1993; Tikoo and Abrol, 1994) ${ }^{[5,1,10] .}$

\section{Study sites}

Geographically Pantnagar is located in the sub-tropical zone at $29^{\circ} \mathrm{N}$ latitude and $79.3^{\circ} \mathrm{E}$ longitude and at an altitude of $243.8 \mathrm{~m}$ above the mean sea level in the "tarai" region of Uttarakhand in Northern India. The location has sub-humid tropical climate and is situated in the foot hills of "Shivalik" range of the Himalayas. The meteorological data indicate that the humid climate here is characterized by hot dry summer and cold winter. The temperature rises up to $40{ }^{\circ} \mathrm{C}$ in summer, while it falls to $2-10{ }^{\circ} \mathrm{C}$ in winter. Approximately, $1400 \mathrm{~mm}$ mean rainfall has been recorded and relative humidity fluctuates around $90 \pm 5$ per cent during rainy season. 

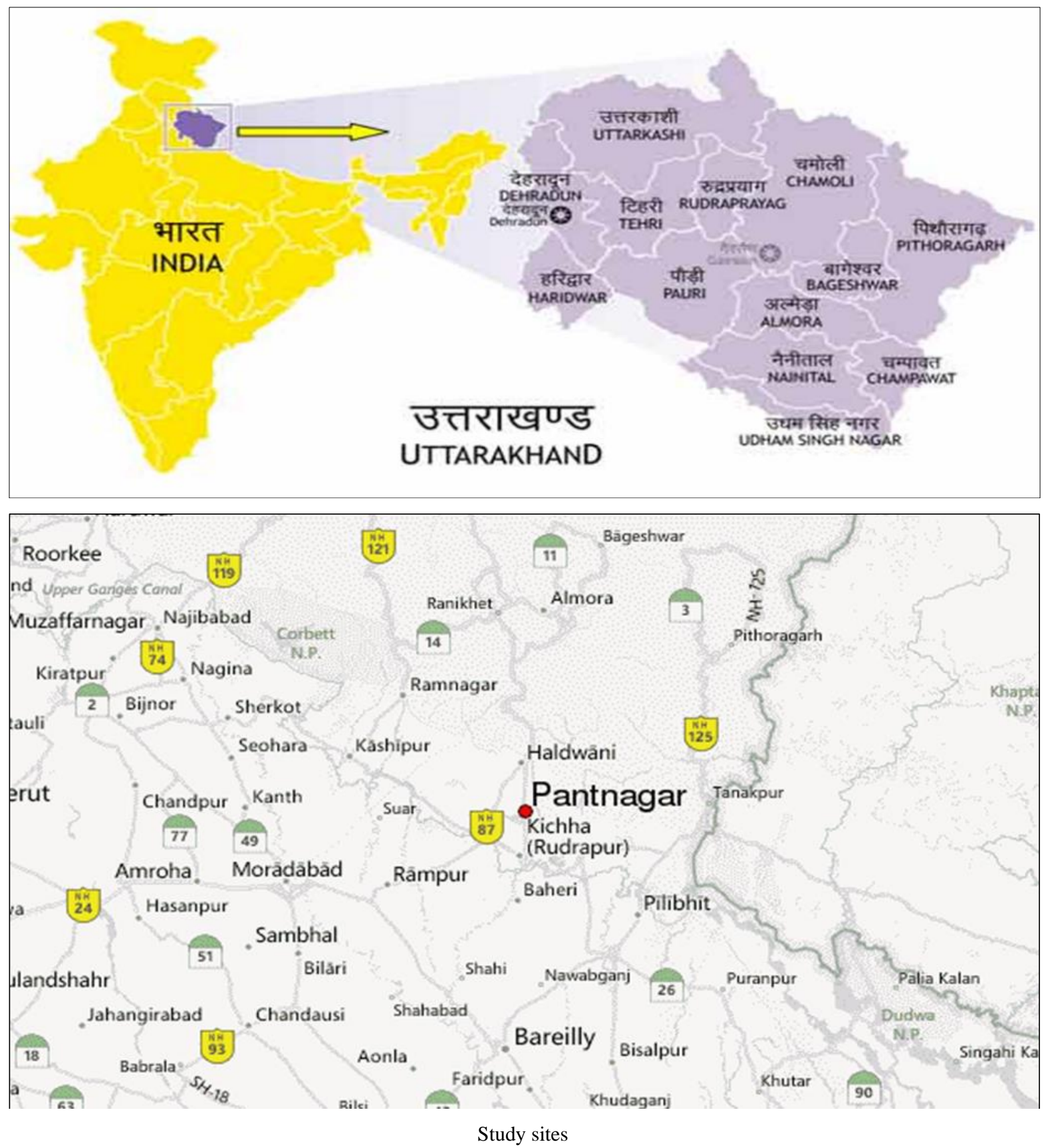

\section{Methodology for}

\section{Biodiversity of insect species on mustard crop}

The study was carried at Model Bee Garden for Research and Training Centre (Pantnagar) during November 2012. Sweepings were made throughout the blooming period of crop at weekly intervals from morning to evening. The collected insects were preserved as dry specimen.

\section{Methodology for}

Foraging behaviour of insect species on mustard crop

Foraging speed of pollinators recorded in terms of time (second) spent by them on each flower and the number of flowers visited per minute following the method given by Free (1993) [5]. To know the foraging speed (time spent/ flower in seconds) at different day hours, the daily observation was taken on insect on Mustard crop at different time intervals such as 0600-0800h, 0800-1000h, 1000-1200h and1600-1800h for 7 days. The time spent to insert the proboscis and suck up the nectar or brushing/collecting pollens was considered as the time spent per flower.
Results and Discussion

Diversity and average time spent by different insect species on mustard crop

A list of insect species visited on Mustard crop at Tarai region of Uttarakhand is presented in Table 01. The hymenopterans were the major floral visitors of comprising of viz. Apidae (Apis dorsata, Apis mellifera, Apis cerana and Apis florea.) are the most frequent insect pollinators. In Mustard Sihag (1988) ${ }^{[9]}$ reported that A.mellifera, A. dorsata, A. florea and Megachile spp. were most numerous visitors of mustard in Hisar. The other insects are Anthophoridae (Xylocopa verticalis, Xylocopa iridipennis, Xylocopa latipes, Amezilla zonata, Amezilla violacea, Anthophora plumipes and Ceratina sexmaculata), Megachilidae (Megachile bicolor, Megachile disjuncta and Megachile hera), Halictidae (Halictus ligatus and Nomia melanderi), Andrenidae (Andrena accepta), Vespidae (Vespa orientalis and Campsomeriella collaris). They were followed in order of diversity by Dipterans (6 species from 2 families) viz. Syrphidae (Eristalis tenax, Episyrphus balteatus, Syrphus corolla and Metasyrphus 
latifascialis) Muscidae (Musca domestica) also observed on Mustard crop.

The data on foraging speed i.e. time spent by different species on Mustard crop at different day hours during Nov-March 2013 at Pantnagar have been presented in table no. 02 and fig. 01. In Apis dorsata mean foraging speed (time spent/ flower in seconds) 8.64 to 11.42 during different day hours of the day, while in case of Apis mellifera, Apis cerana, Apis florea it was 9.85 to $13.08,8.57$ to $9.42,11.42$ to 14.64 seconds. Kumar et al. (1994) ${ }^{[6]}$ considered A. mellifera as the most efficient pollinator of B. campestris L. var. toria. Of the 33 species of bees recorded on some oilseed crops, honeybees (A. florea and $A$. dorsata) were found to be the most efficient pollinators on all the crops as they visited the flowers in large numbers throughout the day and flowering period. Chakravarty (2000) ${ }^{[2]}$ observed the foraging rate of $A$. cerana indica, A. mellifera. A. dorsata and A. florea as 19.25, 18.80, 16.53 and 21.54 flowers/minute. In A. mellifera 11.21 flowers/minute in mustard inside cage by workers and in opens 10.94 flowers/minute. A study carried out by Kumar et al. (1994) ${ }^{[6]}$ revealed that A. mellifera exhibited higher foraging speed than solitary bees on mustard flower. More recently Sharma et al. (2001) ${ }^{[8]}$ reported that A. mellifera spent $1.64 \mathrm{sec} /$ flower followed by $A$. dorsata $2.18 \mathrm{sec} /$ flower and A. florea $3.54 \mathrm{sec} /$ flower on the Brassica campestris var. sarson.

In Hisar, Sihag (1988) ${ }^{[9]}$ reported that the bees Apis dorsata, A. florea, A. mellifera, Andrena ilerda, A. leaena, Megachile bicolor, M. flavipes, M. lantana and M. nana were found on mustard bloom. Amezilla zonata, Amezilla violacea, Anthophora plumipes it was 9.64 to $12.14,9.98$ to 12.00 , and 4.92 to 6.71. Xylocopa verticalis (4.64 to 6.07), Xylocopa latipes (3.85 to 5.92), Xylocopa iridipennis (3.92 to 5.21), Ceratina sexmaculata (9.85 to 11.85), Megachile bicolor (11.92 to 23.00), Megachile disjuncta (11.71 to 22.42), Megachile hera (13.50 to 22.85), Halictus ligatus (14.50 to 24.50), Nomia melanderi (16.28 to 20.42), Musca domestica
(11.92 to 14.78), Eristalis tenax (10.78 to 14.14), Episyrphus balteatus (11.14 to 13.21), Syrphus corollae (9.64 to 14.07) and Metasyrphus latifascialis, it was 10.14 to 13.92 seconds. The maximum time (average 20.35 second) per flower was spent by Halictus ligatus was significantly higher than Megachile bicolor (18.66 second), Nomia melanderi (18.39 second), Megachile hera (18.35 second), Megachile disjuncta (17.02 second), Musca domestica (13.12 second), Apis florea (12.98 second), Eristalis tenax (12.28 second), Episyrphus balteatus (12.28 second), Syrphus corollae (12.26 second), Metasyrphus latifascialis (11.64 second), Apis mellifera (11.37 second), Amezilla violacea (11.08 second), Amezilla zonata (10.96 second), Ceratina sexmaculata (10.48 second), Apis dorsata (10.26 second), Apis cerana (8.90 second), Anthophora plumipes (6.12 second), Xylocopa verticalis (5.33 second), Xylocopa latipes (4.77 second) and Xylocopa iridipennis (4.66 second) respectively. Irrespective of different insect species, the mean time spent during different day hours were varied from 9.85 to 13.85 second. The overall mean of foraging speed of different insect highest during $0800-1000 \mathrm{~h}$ of the day (13.85 seconds/flower) was significantly higher than 1000-1200 (10.99 seconds/flower) and 1600-1800 h (9.85 seconds/ flower). Chaudhary (2001) also reported that honey bees $(58 \%)$, leaf-cutter bee (Megachile hera; $14.4 \%$ proportion), alkali bee (Nomia curvipes; 14.3\%), Chalcidoma creusa (7.8\%), Andrena sacrissima (2.0\%), Sphicodes fumipennis (0.3\%), Braunaspis moderata $(0.1 \%)$, bumble bee (Bombus sp.; $0.1 \%$ ) carpenter bee (Xylocopa sp.; $0.1 \%$ ) syrphid fly (1.3\%), house fly $(0.1 \%)$ and butterfly (Danais sp.; $0.2 \%$ ) as the insect visitors on Brassica campestris var. brown sarson (cv. BSH-1), Brassica carinata cv. Carinata and Indian mustard cultivars RH-30, Laxmi and T-59 in Hisar, Haryana. Similar findings are reported by Saure et al. (2001), who observed great numbers of species of bees (Apidae), hoverflies (Syrphidae) and sawflies (Symphyta) on flowers of rape seed at Michigan State.

Table 1: Diversity of different insect species on Mustard crop at Model Bee Garden for Research and Training Centre (Pantnagar) during November 2012.

\begin{tabular}{|c|c|c|c|c|c|}
\hline Sr. No. & Scientific Name & Order & Family & Foraging Activity & Status \\
\hline 1. & Apis dorsata & Hymenoptera & Apidae & $\mathrm{P}, \mathrm{N}$ & VF \\
\hline 2. & Apis mellifera & Hymenoptera & Apidae & $\mathrm{P}, \mathrm{N}$ & VF \\
\hline 3. & Apis cerana & Hymenoptera & Apidae & $\mathrm{P}, \mathrm{N}$ & VF \\
\hline 4. & Apis florea & Hymenoptera & Apidae & $\mathrm{P}, \mathrm{N}$ & VF \\
\hline 5. & Amezilla zonata & Hymenoptera & Anthophoridae & $\mathrm{P}$ & VF \\
\hline 6. & Amezilla violacea & Hymenoptera & Anthophoridae & $\mathrm{P}$ & VF \\
\hline 7. & Anthophora plumipes & Hymenoptera & Anthophoridae & $\mathrm{P}$ & VF \\
\hline 8. & Xylocopa verticalis & Hymenoptera & Anthophoridae & $\mathrm{P}$ & $\mathrm{F}$ \\
\hline 9. & Xylocopa latipes & Hymenoptera & Anthophoridae & $\mathrm{P}$ & $\mathrm{F}$ \\
\hline 10. & Xylocopa iridipennis & Hymenoptera & Anthophoridae & $\mathrm{P}$ & $\mathrm{F}$ \\
\hline 11. & Ceratina sexmaculata & Hymenoptera & Anthophoridae & $\mathrm{P}$ & $\mathrm{F}$ \\
\hline 12. & Megachile bicolor & Hymenoptera & Megachilidae & $\mathrm{P}$ & $\mathrm{F}$ \\
\hline 13. & Megachile disjuncta & Hymenoptera & Megachilidae & $\mathrm{P}$ & $\mathrm{F}$ \\
\hline 14. & Megachile hera & Hymenoptera & Megachilidae & $\mathrm{P}$ & $\mathrm{F}$ \\
\hline 15. & Halictus ligatus & Hymenoptera & Halictidae & $\mathrm{P}$ & $\mathrm{F}$ \\
\hline 16. & Nomia melanderi & Hymenoptera & Halictidae & $\mathrm{P}$ & $\mathrm{F}$ \\
\hline 17. & Musca domestica & Diptera & Muscidae & $\mathrm{P}$ & $\mathrm{F}$ \\
\hline 18. & Eristalis tenax & Diptera & Syrphidae & $\mathrm{N}$ & VF \\
\hline 19. & Episyrphus balteatus & Diptera & Syrphidae & $\mathrm{N}$ & $\mathrm{F}$ \\
\hline 20. & Syrphus corollae & Diptera & Syrphidae & $\mathrm{N}$ & $\mathrm{F}$ \\
\hline 21. & Metasyrphus latifascialis & Diptera & Syrphidae & $\mathrm{N}$ & $\mathrm{F}$ \\
\hline 22. & Campsomeriella collaris & Hymenoptera & Vespidae & $\mathrm{P}$ & $\mathrm{F}$ \\
\hline 23. & Vespa orientalis & Hymenoptera & Vespidae & - & $\mathrm{F}$ \\
\hline
\end{tabular}

$\mathrm{P}=$ Pollen gatherers, $\mathrm{N}=$ Nectar gatherers, $\mathrm{VF}=$ Very frequent, $\quad \mathrm{F}=$ Frequent, $\mathrm{R}=$ Rare 
Table 2: Average time spent by different insect species on Mustard Crop at different hours of day during November-March 2013 at Pantnagar.

\begin{tabular}{|c|c|c|c|c|c|}
\hline \multirow{2}{*}{ Bee species } & \multicolumn{5}{|c|}{ Time spent/flower (sec) } \\
\hline & 0600-0800 & 0800-1000 & 1000-1200 & $1600-1800$ & Mean \\
\hline Apis dorsata & 11.14 & 11.42 & 9.82 & 8.64 & 10.26 \\
\hline Apis mellifera & 12.57 & 13.08 & 10.00 & 9.85 & 11.37 \\
\hline Apis cerana & 9.42 & 9.00 & 8.62 & 8.57 & 8.90 \\
\hline Apis florea & 14.28 & 14.64 & 11.57 & 11.42 & 12.98 \\
\hline Amezilla zonata & 11.72 & 12.14 & 10.34 & 9.64 & 10.96 \\
\hline Amezilla violacea & 11.92 & 12.00 & 10.41 & 9.98 & 11.08 \\
\hline Anthophora plumipes & 6.42 & 6.71 & 6.42 & 4.92 & 6.12 \\
\hline Xylocopa verticalis & 5.70 & 6.07 & 4.92 & 4.64 & 5.33 \\
\hline Xylocopa latipes & 5.22 & 5.92 & 4.07 & 3.85 & 4.77 \\
\hline Xylocopa iridipennis & 5.21 & 4.78 & 4.71 & 3.92 & 4.66 \\
\hline Ceratina sexmaculata & 10.28 & 11.85 & 9.92 & 9.85 & 10.48 \\
\hline Megachile bicolor & 21.35 & 23.00 & 18.35 & 11.92 & 18.66 \\
\hline Megachile disjuncta & 21.00 & 22.42 & 12.94 & 11.71 & 17.02 \\
\hline Megachile hera & 21.78 & 22.85 & 15.28 & 13.50 & 18.35 \\
\hline Halictus ligatus & 23.57 & 24.50 & 18.85 & 14.50 & 20.35 \\
\hline Nomia melanderi & 19.71 & 20.42 & 17.14 & 16.28 & 18.39 \\
\hline Musca domestica & 13.21 & 14.78 & 12.57 & 11.92 & 13.12 \\
\hline Eristalis tenax & 13.35 & 14.14 & 10.85 & 10.78 & 12.28 \\
\hline Episyrphus balteatus & 12.85 & 13.21 & 11.92 & 11.14 & 12.28 \\
\hline Syrphus corollae & 13.64 & 14.07 & 11.71 & 9.64 & 12.26 \\
\hline Metasyrphus latifascialis & 12.21 & 13.92 & 10.28 & 10.14 & 11.64 \\
\hline \multirow[t]{2}{*}{ Mean } & 13.17 & 13.85 & 10.99 & 9.85 & 11.96 \\
\hline & & \multicolumn{2}{|c|}{$\mathrm{SE}(\mathrm{m})$} & \multicolumn{2}{|c|}{ C.D. $(\mathrm{p}=0.05)$} \\
\hline \multicolumn{2}{|c|}{ Bee species } & \multicolumn{2}{|c|}{0.31} & \multicolumn{2}{|c|}{0.88} \\
\hline \multicolumn{2}{|c|}{ Day hours } & \multicolumn{2}{|c|}{0.13} & \multicolumn{2}{|c|}{0.38} \\
\hline \multicolumn{2}{|c|}{ Bee species $\mathrm{x}$ day hours } & \multicolumn{2}{|c|}{0.63} & \multicolumn{2}{|c|}{1.77} \\
\hline \multicolumn{2}{|c|}{$\mathrm{CV}$} & \multicolumn{4}{|c|}{14.09} \\
\hline
\end{tabular}

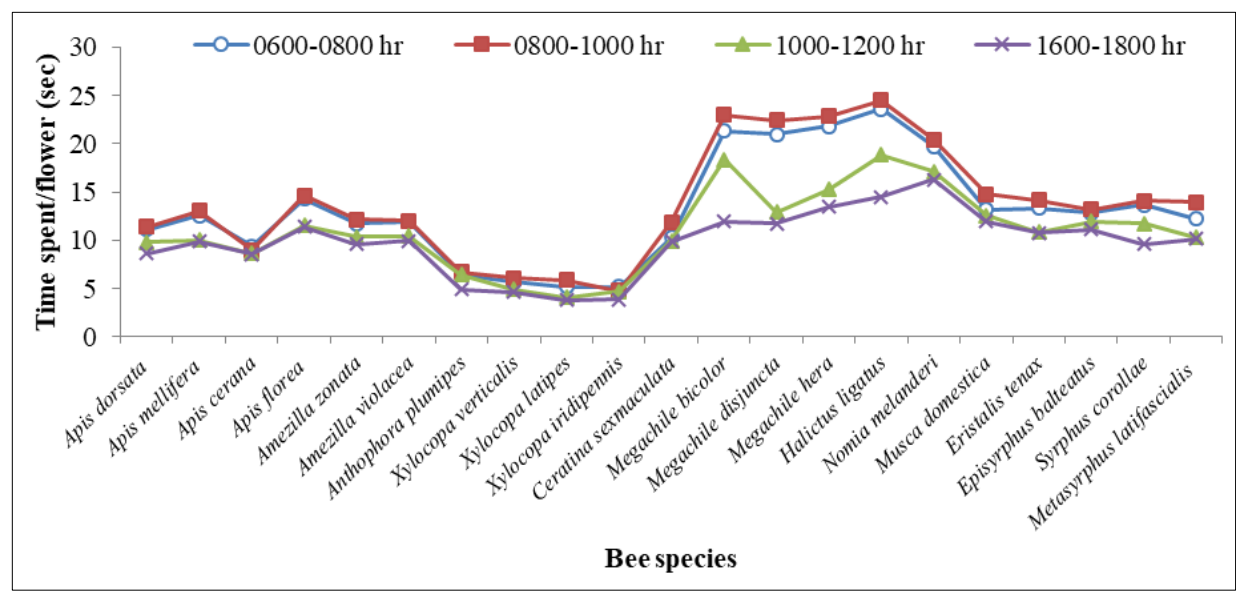

Fig 1: Average time spent by different insect species on Mustard Crop at different hours of day during November-March 2013 at Pantnagar

\section{References}

1. Abrol DP. Insect pollinators and crop production in Jammu and Kashmir. Current Science. 1993; 65(3):265269.

2. Chakravarty MK. Foraging behaviour and pollination efficiency of honeybees in hybrid seed production of Brassica napus L. Thesis (Ph.D., Entomology) submitted to GBPUAT, Pantnagar- 263145, (U.S. Nagar), Uttaranchal, India, 2000, 141.

3. Chaudhary OP. Abundance of wild pollinators on rapeseed and mustard. Insect Environment. 2001; 7(3):141-142.

4. Das CS, Chodhury KR. Floral biology of litchi. South Indian Horticulture. 1968; 6:17-22.

5. Free JB. Insect pollination of crops. London, Academic Press. London, U.K., 1993, 684.

6. Kumar J, Rao KVK, Gupta JK. Pollination efficiency of bees visiting blossoms of Brassica campestris L. var toria in mid-hills of Himachal Pradesh, India. Indian Bee Journal. 1994; 56:202-206.
7. Saure C, Kuhne S, Hommel B. Pollen transfer by insects from oilseed rape to other crucifers: contribution to the risk assessment of genetically modified plants. Mitteilungen-der-Deutschen-Gesellschaft-fur-allgemeineund-ngewandte-Entomologie. 2001; 13(1-6):265-268.

8. Sharma SK, Singh JR, Mahla JC. Foraging behaviour of Apis spp. in semi-arid sub-tropical climate on flowers of mustard, onion, carrot, berseem and sunflower in Hisar, India. Crop Research. 2001; 21(3):332-334.

9. Sihag RC. Characterization of the pollinators of cultivated cruciferous and leguminous crops of subtropical Hisar, India. Bee World. 1988; 69(4):153-158.

10. Tikoo RK, Abrol DP. Apiculture in agroforestry to boost rural economy. In: Agroforestry systems for degraded lands Punjab Singh; P.S. Pathak and M.M. Roy (eds.). Proceedings of the International conference on sustainable development of degraded lands through agroforestry in Asia and the Pacific New Delhi. 1994; 1:507-513 